\title{
EFFECT OF FAZADINIUM (FAZADON) ON MUSCLE FASCICULATIONS INDUCED BY SUCCINYLCHOLINE
}

\author{
C.E. FAMEwo
}

\begin{abstract}
The effects on muscle fasciculations and ease of tracheal intubation of pretreatment with fazadinium before administration of succinylcholine were evaluated in 85 patients. Four dose levels of fazadinium evaluated were $0.05 \mathrm{mg} \cdot \mathrm{kg}^{-1}, 0.075 \mathrm{mg} \cdot \mathrm{kg}^{-1}, 0.10 \mathrm{mg} \cdot \mathrm{kg}^{-1}$ and $0.15 \mathrm{mg} \cdot \mathrm{kg}^{-1}$. The $0.05 \mathrm{mg} \cdot \mathrm{kg}^{-1}$ dose did not always prevent succinylcholine-induced muscle fasciculations. The $0.15 \mathrm{mg} \cdot \mathrm{kg}^{-1}$ dose gave poor conditions for tracheal intubation and was therefore discontinued. The $0.075 \mathrm{mg} \cdot \mathrm{kg}^{-1}$ dose seemed optimal.

Most patients felt transient pain at the site of the injection during administration of fazadinium. and many had a sensation of drowsiness.
\end{abstract}

Key Words: Neuromuscular Relaxants, Fazadinium, Succinylcholine.

THE DEPOLARISING MUSClE RELAXANT succinylcholine produces very satisfactory muscle relaxation for tracheal intubation. However, its administration often produces muscle fasciculations before muscle relaxation. These muscle fasciculations are thought to be responsible for the undesirable increases in intragastric' and intra-ocular ${ }^{2}$ pressures as well as the hyperkalaemia ${ }^{3}$ and post-operative muscle pains ${ }^{4.5}$ that have been reported following succinylcholine administration. Previous investigators have reported that small subparalysing doses of nondepolarising muscle relaxants such as d-tubocurarine, gallamine and pancuronium can attenuate or prevent these undesirable effects if given before administration of succinylcholine. ${ }^{6-8}$

The aim of this study is to establish whether pre-treatment with fazadinium, a new nondepolarising muscle relaxant, will prevent succinylcholine fasciculations and, if so, to determine the minimum dose level of fazadinium that consistently achieves this result.

\section{Materials ANd METHODS}

Eight-five Nigerian patients (ASA physical status 1 or 2) scheduled for elective surgery were studied. The patients gave informed consent. There were 40 males and 45 females. Their ages ranged between 20 and 65 years while their weights were between $60 \mathrm{~kg}$ and $75 \mathrm{~kg}$. Fifty-five

C.E. Famewo, M.B., B.S. Dip. Anaes. (Toronto), F.R.C.P(C), Consultant Anaesthetist, College of Medicine, University of Ibadan, University College Hospital, Ibadan. Nigeria. patients were premedicated with intramuscular meperidine $1 \mathrm{mg} \cdot \mathrm{kg}^{-1}$ one hour before anaesthetic induction, while the remaining 30 patients were not premedicated. All patients received atropine $0.6 \mathrm{mg}$ intravenously at the time of induction of anaesthesia. Anaesthesia was induced in each patient with a sleep dose of thiopentone, followed by administration of succinylcholine bromide $40 \mathrm{mg}$ intravenously. Four dose levels of fazadinium were investigated. Group 1: $0.005 \mathrm{mg} \cdot \mathrm{kg}^{-1}$; Group 2: $0.075 \mathrm{mg}$. $\mathrm{kg}^{-1}$; Group 3: $0.10 \mathrm{mg} \cdot \mathrm{kg}^{-1}$ and Group 4: 0.15 $\mathrm{mg} \cdot \mathrm{kg}^{-1}$. Patients received these different dose levels in a random fashion. The doses were given about three minutes before induction of anaesthesia and succinylcholine administration in each instance. Twenty-five patients were assigned to each dose level. However, only 10 patients received the $0.15 \mathrm{mg} \cdot \mathrm{kg}^{-1}$ dose, because this dose level was discontinued due to the poor muscle relaxation obtained after succinylcholine administration. Twenty-five patients were studied at each of the other dose levels of 0.10 $\mathrm{mg} \cdot \mathrm{kg}^{-1}, 0.075 \mathrm{mg} \cdot \mathrm{kg}^{-1}$ and $0.05 \mathrm{mg} \cdot \mathrm{kg}^{-1}$. Fasciculations were graded as follows:

$$
\begin{aligned}
& 0=\text { No fasciculations } \\
& 1=\text { Minimal and localized fasciculations } \\
& 2=\text { Generalized but moderate } \\
& 3=\text { Generalized and severe }
\end{aligned}
$$

The ease of intubation was graded using the method of Lund and Stovner. 9 The gradings of fasciculations and ease of intubation were all done by the author to ensure consistency. The different doses of fazadinium (unknown to the author at the time) were given by an assistant.

Canad. Anaesth. Soc. J., vol. 28, no. 5, September 1981 
TABLE !

Fasciculations Following Succinylcholine

\begin{tabular}{|c|c|c|c|c|c|c|c|c|}
\hline \multirow[b]{2}{*}{ Group } & \multirow{2}{*}{$\begin{array}{c}\text { Dose of } \\
\text { Fazadinium }\end{array}$} & \multirow{2}{*}{$\begin{array}{l}\text { No. of } \\
\text { Patients }\end{array}$} & \multicolumn{4}{|c|}{ Fasciculations } & \multirow[b]{2}{*}{ Total } & \multirow[b]{2}{*}{ Per cent } \\
\hline & & & 0 & 1 & 2 & 3 & & \\
\hline 1 & $0.05 \mathrm{mg} \cdot \mathrm{kg}^{-1}$ & 25 & 9 & 10 & 6 & - & 16 & 64 \\
\hline 2 & $0.075 \mathrm{mg} \cdot \mathrm{kg}^{-1}$ & 25 & 25 & - & - & - & 0 & 0 \\
\hline 3 & $0.010 \mathrm{mg} \cdot \mathrm{kg}^{-1}$ & 25 & 25 & - & - & - & 0 & 0 \\
\hline 4 & $0.15 \mathrm{mg} \cdot \mathrm{kg}^{-1}$ & 10 & 10 & - & - & - & 0 & 0 \\
\hline
\end{tabular}

Students t-test was used for statistical comparison of groups.

\section{RESULTS}

None of the patients pretreated with fazadinium at the dose levels between $0.075 \mathrm{mg} \cdot \mathrm{kg}^{-1}$ and $0.15 \mathrm{mg} \cdot \mathrm{kg}^{-1}$ showed muscle fasciculations. However, fasciculations were observed in 64 per cent of the patients who received the 0.05 $\mathrm{mg} \cdot \mathrm{kg}^{-1}$ dose (Table $\mathbf{l}$ ). This difference between pre-treated and untreated patients is statistically significant $(p<0.01)$. A reduction in the degree of muscle relaxation produced by succinylcholine was evident following pre-treatment with fazadinium. This was most marked at the $0.15 \mathrm{mg} \cdot \mathrm{kg}^{-1}$

TABLE II

INTUBation CONDITIONS, LUND \& STOVNER GRADING*

\begin{tabular}{ccccc}
\hline & $\begin{array}{c}\text { Number } \\
\text { of } \\
\text { Group }\end{array}$ & \multicolumn{3}{c}{ Intubation Grading* } \\
\cline { 4 - 6 } & Patients & 1 & 2 & 3 \\
\hline 1 & & & & \\
$\left(0.05 \mathrm{mg} \cdot \mathrm{kg}^{-1}\right)$ & 25 & $\begin{array}{c}2 \\
(8 \%)\end{array}$ & $\begin{array}{c}10 \\
(40 \%)\end{array}$ & $\begin{array}{c}13 \\
(52 \%)\end{array}$ \\
$\begin{array}{ccccc}2 \\
\left(0.075 \mathrm{mg} \cdot \mathrm{kg}^{-1}\right)\end{array}$ & 25 & 4 & 11 & 10 \\
3 & & $(16 \%)$ & $(44 \%)$ & $(40 \%)$ \\
$\left(0.10 \mathrm{mg} \cdot \mathrm{kg}^{-1}\right)$ & 25 & 9 & 12 & 4 \\
4 & & $(36 \%)$ & $(48 \%)$ & $(16 \%)$ \\
$\left(0.15 \mathrm{mg} \cdot \mathrm{kg}^{-1}\right)$ & 10 & 9 & 1 & - \\
& & $(90 \%)$ & $(10 \%)$ & \\
\hline
\end{tabular}

*Grade 3 - Excellent. Well separated cords not moving, no bucking on tube.

Grade 2 - Satisfactory. Slight movement of cords when touched, slight bucking.

Grade 1 - Fair. Condition less favourable than in the previous category but permitting intubation. dose. The ease of intubation using the grading of Lund and Stovner ${ }^{9}$ is shown in Table II. Excellent (grade 3) conditions for intubations were obtained in 52 per cent of patients in group 1,40 per cent in group 2, 16 per cent in group 3 and none in group 4.

Most of the patients complained of pain at the site of injection during administration of fazadinium. The pain was usually transient and could be minimized by rapid flushing with intravenous infusion. Many of the patients stated that they felt "drowsy" or "dizzy" following the administration of these subparalysing doses of fazadinium in the conscious state.

\section{Discussion}

Previous investigations have shown that fazadinium in doses between $1.0 \mathrm{mg} \cdot \mathrm{kg}^{-1}$ and 1.5 $\mathrm{mg} \cdot \mathrm{kg}^{-1}$ give quick and satisfactory conditons for tracheal intubation. ${ }^{10,11}$ Fazadinium can therefore be used as an alternative to succinylcholine in situations where the undesirable sideeffects of succinylcholine are best avoided. However, the longer duration of effect (40 to 60 minutes) of fazadinium as compared with succinylcholine ( 3 to 5 minutes) makes fazadinium unsuitable for very short procedures where relaxation is needed only for tracheal intubation and spontaneous respiration is intended during the maintenance of anaesthesia. In such cases, pretreatment with a small dose of fazadinium allows succinylcholine to be used with greater safety.

The results in this study indicate that doses of fazadinium between $0.075 \mathrm{mg} \cdot \mathrm{kg}^{-1}$ and 0.15 $\mathrm{mg} \cdot \mathrm{kg}^{-1}$ effectively prevent fasciculations induced by succinylcholine, while the $0.05 \mathrm{mg} \cdot \mathrm{kg}^{-1}$ dose was not always effective. Poorer scores for the ease of tracheal intubation were obtained when the $0.15 \mathrm{mg} \cdot \mathrm{kg}^{-1}$ dose of fazadinium was used (Table II) and patients sometimes made 
gross movement of their limbs when intubation was attempted; hence the abandonment of this dose level at an early stage of the study. No patient however had any recall post-operatively. The dose of $0.15 \mathrm{mg} \cdot \mathrm{kg}^{-1}$ is therefore not recommended because of the unacceptably poor conditions for intubation. When the results were analysed with respect to administration of meperidine and the occurrence of muscle fasciculations, no relation could be established, indicating that premedication with meperidine did not influence the occurrence of succinylcholineinduced fasciculations.

The dose of $40 \mathrm{mg}$ of succinylcholine bromide used in this study is between $0.53 \mathrm{mg} \cdot \mathrm{kg}^{-1}$ and $0.66 \mathrm{mg} \cdot \mathrm{kg}^{-1}$ body weight, representing only 10 per cent maximum variation from the commonly used standard dose of $0.6 \mathrm{mg} \cdot \mathrm{kg}^{-1}$.

The pain experienced by most of the patients during injection of fazadinium is probably due to local irritant effect on the vessel. The feeling of drowsiness expressed by some of the patients in this study has also been reported by Dery ${ }^{12}$ in a group of conscious patients pretreated with curare. It is possible that this feeling of drowsiness is due to muscle weakness and lid-drooping caused by the sub-paralysing dose of fazadinium rather than to true sedation.

Of the four dose levels investigated, the $\mathbf{0 . 0 5}$ $\mathrm{mg} \cdot \mathrm{kg}^{-1}$ dose level failed to prevent fasciculations in 64 percent of patients while the 0.15 $\mathrm{mg} \cdot \mathrm{kg}^{-1}$ dose gave less than favourable conditions for intubation in 90 percent of patients. Whereas both the $0.075 \mathrm{mg} \cdot \mathrm{kg}^{-1}$ and the 0.10 $\mathrm{mg} \cdot \mathrm{kg}^{-1}$ doses completely abolished muscle fasciculations, excellent conditions for tracheal intubation (Lund and Stovner grade 3) were more frequent with the $0.075 \mathrm{mg} \cdot \mathrm{kg}^{-1}$ dose ( 40 per cent of patients) as compared with the $0.10 \mathrm{mg} \cdot \mathrm{kg}^{-1}$ dose (16 per cent of patients). The $0.075 \mathrm{mg} \cdot \mathrm{kg}^{-1}$ dose therefore appears to be optimal in terms of abolishing muscle fasciculations with the least compromise of muscle relaxation for tracheal intubation. If the $0.10 \mathrm{mg} \cdot \mathrm{kg}^{-1}$ dose is used, a larger dose of succinylcholine $0.9 \mathrm{mg} \cdot \mathrm{kg}^{-1}$ will be desirable to ensure better relaxation. Similar antagonism to relaxation produced by succinylcholine has been reported following pretreatment with d-tubocurarine, pancuronium, and gallamine ${ }^{13-15}$. Consequently, some investigators have recommended larger doses of succinylcholine to achieve satisfactory muscle relaxation following pretreatment with these non-depolarising muscle relaxants. ${ }^{16.17}$
In conclusion, pretreatment with fazadinium can prevent fasciculations induced by succinylcholine. The minimal effective dose with least compromise of the ease of intubation is 0.075 $\mathrm{mg} \cdot \mathrm{kg}^{-1}$. Pretreatment with fazadinium is recommended to prevent succinylcholine-induced fasciculations and the associated complications.

\section{ACKNOWLEDGEMENT}

I wish to thank Mr. Taiye Ogunsanya of the Department of Anaesthesia, College of Medicine, University College Hospital, Ibadan for his expert secretarial assistance.

\section{REFERENCES}

1. RoE, R.B. The effect of Suxamethonium on intragastric pressure. Anaesthesia 17: 179 (1962).

2. Craythome, N.W.B., Rotrenstein, H.S. \& DrIPPS, R.D. The effect of Succinylcholine on intraocular pressure in adults, infants and children during general anaesthesia. Anesthesiology 21:59 (1960).

3. Mazze, R.I., Escue, H.M. \& Houston, J.B. Hyperkalaemia and cardiovascular collapse following administration of succinylcholine in the traumatised patient. Anesthesiology 31:540 (1969).

4. Churchill-Davidson, H.C. Suxamethonium and muscle pains. Brit. Med. J. 1, 74 (1954).

5. Morris, D.D.B. \& DunN, C.H. Suxamethonium chloride administration and post-operative muscle pain. Brit. Med. J. I, 383 (1957).

6. LACouR, D. Prevention of rise in intragastric pressure due to Suxamethonium fasciculations by prior dose of d-tubocurarine. Acta Anaesth. Scand. 14:5 (1970).

7. Miller, R.D., WAY, W.L. \& HiCKEY, R.F. Inhibition of succinylcholine-induced increased intraocular pressure by non-depolarising muscle relaxants. Anesthesiology 29: 123 (1968).

8. Antony D. Ivankovich, et al. Dual action of Pancuronium on Succinylcholine block. Canad. Anaesth. Soc. J. 24: 228 (1977).

9. LUND, I. \& Stovner, J. Dose response curves for Tubo curarine, Alcuronium and Pancuronium. Acta. Anaesth. Scand. Suppl. 37, 238 (1970).

10. Famewo, C.E. Clinical Trial of Fazadinium bromide (Fazadon). Canad. Anaesth. Soc. J. 28: 149 (1981).

11. Coleman, A.J., O'Brien, A. et al. A.H. 8165, a new non-depolarising muscle relaxant. Anaesthesia 28: 262 (1973).

12. DERY, R. The effects of Precurarication with a protective dose of d-Tubocurarine in the conscious patient. Canad. Anaesth. Soc. J. 2l:68(1974).

13. WALTS, L.F. \& Dillon, J.B. Clinical studies of the interaction between d-Tubocurarine and Succinylcholine. Anesthesiology 31: 39 (1969).

14. Domgoal, A.M., Weniger, F.C. \& Wolfson, B. "Precurarization" using Pancuronium. Anesth. Analg. 54: 71 (1975) 
15. Bennt, E.J., Montgomery. S.J., Dalal, F.Y. et al. Pancuronium and the fasciculations of Succinylcholine. Anesth. Analg. 52: 892 (1973).

16. Freund, F.G. \& Rubin, A.P. The need for additional succinylcholine after $d$-Tubocurarine. Anesthesiology 36: 185(1972).
17. Cullen. D.J. The effect of pretreatment with non-depolarizing muscle relaxants on the neuromuscular blocking action of Succinylcholine. Anesthesiology 35: 572 (1971).

\section{RÉSUMÉ}

On a étudiè sur 85 patients les effets du pré-traitement au fazadinium sur les fasciculations musculaires et sur l'intubation trachéale. On a évalue quatre dosages de fazadinium soit 0.05 $\mathrm{mg} \cdot \mathrm{kg}^{-1} 0.075 \mathrm{mg} \cdot \mathrm{kg}^{-1}, 0.10 \mathrm{mg} \cdot \mathrm{kg}^{-1}$ et $0.15 \mathrm{mg} \cdot \mathrm{kg}^{-1}$. La dose de $0.05 \mathrm{mg} \cdot \mathrm{kg}^{-1} \mathrm{n}$ 'a pas toujours prévenu les fasciculations induites par la succinylcholine. L'emploi de la dose de $0.15 \mathrm{mg} \cdot \mathrm{kg}^{-1}$ a produit des conditions défavorables pour l'intubation trachéale et a du être discontinué. La dose de $0.075 \mathrm{mg} \cdot \mathrm{kg}^{-1}$ a semblé optimale. La plupart des patients ont ressenti une douleur transitoire au site d'injection pendant l'administration du fazadinium et plusieurs ont décrit une sensation de somnolence. 